of 350 miles, undertaken with the view of aiding the Rev. C. T. Wilson, and he promises a detailed account of his troubles then on another occasion. In the course of this march he had to cross the extensive wilderness of Mgunda.Mkali, which he describes as being for the most part not merely a swamp, but this year more under water than above it. Day after day the party waded and splashed through mud and water, now over the ankles, sometimes up to the knee, and here and there up to the waist or higher. Hopeless and still more hopeless, Mr. Mackay remarks, the wading seemed to become, and he found that they were crossing what was neither more nor less than the source at once of the Nile, the Congo, and the Rufiji. This gigantic boggy plain or moss Cameron calls the Nya Kun Swamp, and, where Mr. Mackay crossed it, in S. lat. $5^{\circ} 20^{\prime}$, his aneroids recorded an average elevation of 4,000 feet exactly. To the north, in Usukuma, the swamp narrows itself into the sluggish Lewumberi River, the most southerly of the sources of the Nile. From this swamp, too, the rapid Mdaburu River takes its rise, and flows southward into the Ruaha, in Unyoro, and Uhehe, and thence to the Indian Ocean, where it is known as the Rufiji. A day's march east of Tura Mr. Mackay found the swanip contract to a breadth of 300 yards, with increased depth, and slight indications of flow to the southward; it then rounds to the west, steering clear of Iive-la-Singa, and, after two more days, it was crossed-a flooded, five-armed siver, flowing rapidly north at an altitude of 3,700 feet. Here it is called the Nghwala River by the Wanyamwezi, from the number of partridges on its banks. In Speke's map alone it would seem that the true course of the river is indicated; it flows north-east to Mirambo's country, where it is known as the Ngombe (i.e., ox) River, and finds its way into the Malagarasi, thus aiding that river in bringing Lake Tanganyika nearer to permanent overflowing, when the Lukuga-which has been such a bone of contention to two great travellers - will no longer be a swamp but a decided stream, and the waterline of the Congo will run from Loango on the West Coast to the confines of Ugogo.

THE London Missionary Society have received a letter from the Rev. J. B. Thomson, dated from Ujiji, announcing the safe arrival on August 23 of the main body of the Society's expedition at its destination on Lake Tanginyika. Though, as will be remembered, this expedition Divet with a long series of disasters and delays in the coast region, they have now been successful in performing one of the quickest and most prosperous journeys from Mpwapwa to $\mathrm{Ujiji}$, having been but seventy-three days on the road. Messris. Thomson and Hore have aiready found an apparently healthy site for their station close to Kinegoma Bay, and about three miles from Ujiji.

WE learn from a Japan paper that an American gentleman has been engaged for some time past in surveying the Island of Yezo, as well as in making geological investigations. The result is said to be that there are 7,000 square miles of land fit for agricultural purposes, and 6,000 suitable for pasture, while there are 5,000 square miles of forests and 9,000 of volcanic mountains and mineral country. An impression appears to prevail that the Government wish to encourage emigration to this thinly-populated part of the Japanese empire.

As an erroneous impression prevails that nothing is known of the scientific work done by the Portuguese African expedition previous to the date mentioned in last week's NATURE, it may be interesting to give, as instances of the service which they are rendering to geography, the positions of some of the places determined by Senhor Serpa Pinto and his colleagues:-Benguela, long. $13^{\circ} 25^{\prime} 20^{\prime \prime} 45^{\prime \prime \prime}$, lat. $12^{\circ} 34^{\prime} 17^{\prime \prime}$, alt. 7 metres; I) ombe Grande, long. $13^{\circ} 7^{\prime} 45^{\prime \prime}$, lat. $12^{\circ} 55^{\prime \prime} 12^{\prime}$, alt. 98 metres ; Quillenques, long. $14^{\circ} 5^{\prime} 3^{\prime \prime}$, lat. $14^{\circ} 3^{\prime} 10^{\prime \prime}$, alt. 900 metres; Caconda, long. $15^{\circ} \mathrm{I}^{\prime} 5 \mathrm{I}^{\prime \prime}$, lat. $13^{\circ} \mathrm{o}^{\prime} 44^{\prime \prime}$, alt. 1,678 metres ; Bihé, long. $16^{\circ} 49^{\prime} 24^{\prime \prime}$, lat. $12^{\circ} 22^{\prime} 40^{\prime \prime}$, alt. I,670 metres. The longitudes are stated to be chronometrical.

DR. EDWIN R. HEATH, of Wisconsin, is about undertaking the exploration of the Beni and Madre di Dios Rivers of Brazil, his sojourn in South America some years as secretary of legation in Chili giving him excellent advantages for this purpose. Dr. Heath had arranged to visit South America with Prof. Orton, but was detained, and he now desires to carry out some of the work that the untimely death of that well-known explorer has left uncompleted.

THE latest advices from Mr. Frederick A. Ober, of whose explorations in the West Indies on account of the Smithsonian Institution we have given notice from time to time, were from Point a Pitre, Guadeloupe, on September 23. He was about to leave for the United States; expecting to arrive some time between the middle and end of October. Since his last report he has obtained quite a number of additional collections, and hoped to complete the material for the proposed catalogue of the birds of the West Indies. So far the collections sent forward by him to the Smithsonian Institution have been found to contain some seventeen undescribed species of birds, as determined by Mr. George N. Lawrence, of New York.

AN interesting" account of a recent visit to Pitcairn Island by Admiral De Horsey in the Shak, forwarded to the Admiralty, will be found in yesterday's Daily New's. The people are evidently as primitive and well-conducted, and on the whole as comfortable as ever.

IN a previous number we referred to a work of great geographical interest-" "Die Sahara, von Oase zu Oase," by Dr. Joseph Chavanne, published by Hartleben, of Vienna. At that time the work was in course of publication, and we refer to it now to announce its completion in twenty parts. The last parts are in every way equal to the earlier ones, and if anything the interest is rather increased than otherwise. The work contains numerous woodcuts, besides seven coloured plates and a map of the great desert ; its perusal will be found extremely attractive by any one taking interest in geographical science. The exact route which Dr. Chavanne describes is the following:--The travellers start from Tripolis through the Fezzan to Mursuk, then westward to Rhat, the land of the Tuareg or Imoshag. From Rhat they turn northward to Rhadames, thence to Biskra in Algeria. Here the travellers again turn their backs to the Mediterranean and proceed in a south-westerly direction by way of El Aruat and El Golea to Insalah. From Insalah they go to Tafilet, in the extreme north-west of the desert, and thence many thousand miles to the south to Timbuctoo. The Oasis of Air or Asben is the next station, situated due east from Timbuctoo, then Tibesti, the land of the Tebbu. Thence they turn to the northeast to the Jupiter Ammon Oasis, which is the furthest point to the east reached. The travellers then turn westward again and return to Tripolis by way of Audschila.

ON THE DEVELOPMENT OF THE GARPIKE

THE gar or bony pike of North America is one of the 7 most interesting of living tishes. The best known species of the genus to which it belongs is the Lepidosterts osserts. This species owes the grammatical form of its scientific name, and, indeed, its first scientific description to the elder Agassiz, and we have now to record the filling up of the last details of its life-history to the younger Agassiz. Known for over three-quarters of a century, it has been only within the last few months that the young fish as they escape from the egg have been 
seen, and it has been the good fortune of Alexander Agassiz to succeed in hatching the eggs and raising the young until they showed at least the principal structural peculiarities of the adult. A short account of the chief facts in connection with this stage of the bony pike's history will appear in the forthcoming number of the Proceedings of the American Academy of Arts and Sciences; from an advance copy we cull the following details:The spawning-ground selected for observation was the Black Lake, at Ogdensburgh, N.Y. Mr. Garman, who describes the scene, and Mr. Blodgett, who rendered most essential assistance, deserve the thanks of every naturalist. The eggs collected were carried by the hand in pails from Ogdensburgh to Cambridge, where their progress was watched by Prof. A. Agassiz.

The fish began to spawn about May 18. Little projections of granite stand out here and there into the lake. The frosts from time to time have broken off from these, small angular blocks, which lie piled together under the water at depths varying from two to fourteen inches. Into these shallows the female fish would come, each of them attended by two males. While very timid when in deep water, they seemed to be courageous to recklessness when they approached the shallows. On they would come in threes, when rising to the surface of the water, and thrusting their bill out of it they would open shis widely, then take in air, and close it with a snap. In some few cases three or four males would be in attendance on one female, but much more often there would be but two, and these would swim resting on either side of the female fish, their bills reaching up toward the back of her head. At times the water would be lashed into all directions with their conjoined convulsive movements. The eggs when laid were excessively sticky; to whatever they happened to touch they stuck, and so tenaciously, that it was next to impossible to release them without tearing away a portion of their envelopes. It is remarkable that, as far as could be seen, there was, on and about the spawning ground, a complete absence of anything that might serve as food for the young fish.

Of the quantity of eggs brought to Cambridge, only thirty hatched, and not one of those artificially fecundated was hatched. In Prof. A. Agassiz' anxiety not to spoil this interesting experiment he did not venture to examine any of the fresh eggs; so that the history of their segmentation and very early development remains to be worked out. The envelope of the eggs is very opaque and of a yeilowish green, like that of toads. Of the thirty hatched out by the end of May, twenty-eight were alive in the middle of July last. When first hatched the young fish possesses a gigantic yolk-bag, and the posterior part of the body presented nothing specially differcnt from the general appearance of any ordinary bony (teleostean) fish of the same age; but the anterior part was most extraordinary: it looked like a huge mouth cavity, extending nearly to the gill opening, and crowned by a depression like a horse's hoof in outline, along the margin of which were a row of protuberances acting as suckers. The moment the young fish was hatched it attached itself to the sides of the vessel by means of these, and would hang immovable. The eye was not very advanced, the body was transparent, the gill covers were pressed against the sides of the body; the tail was slightly rounded, the embryonic fin is narrow, and there were no traces of embryonic fin rays; the olfactory lobes were greatly developed and elongated as in sharks and skates; the chorda was straight. On the third day the body became covered with minute black pigment cells, and then was noted the first traces of the pectoral fins, and the snout became more elongated; the great yolk-bag was greatly reduced in size. About the fifth day were seen traces of the caudal, dorsal, and anal fins. Gradually the snout became elongated, the suckers concenrrated, and the disproportionate size of the sucking disc became reduced, so that when about three weeks old it became altogether more fish-like. The sucking disc was now reduced to a swelling at the top of the upper jaw, the yolk-bag had disappeared, the gill covers extended well up to the base of the pectorals-these latter were in constant motion, and the tail exhibited the same rapid vibratile movements. Theyoung fish now begins to swim about, and is not so dependent upon its sucking disc, and at last this only remains as a fleshy globular termination on the snout. At this stage, too, the young have the peculiar habit of the adult fish of coming to the surface to swallow air. When they go through the process under water of expiring this air they open their jaws wide and spread their gill-cover, and swallow as if they were choking, making violent efforts, until a minute bubble of air has become liberated, when they become quiet again. Their growth is rapid. Within a month the teeth made their appearance, and some of the fin-rays on the fringe of the pectorals were to be seen.

Prof. A. Agassiz draws the following conclusions from these observations:- "That notwithstanding its similarity" in certain stages of its growth to the sturgeon, notwitbstanding its affinity with sharks by the formation of its pectorals from a lateral fold, as well as by the mode of growth of the gill openings and gill arches, the Lepidosteus is not at all so far removed as is generally supposed from the bony fishes." The memoir is illustrated by five plates containing some forty-five figures, and is only to be regarded as a preliminary account, but it is a preliminary account of such exactness, importance, and interest, that no apology is necessary for bringing it at once under the notice of our readers. This memoir was presented to the American Academy as recently as October 8 last.

E. PERCEVAL WRIGHT

\section{THE MUSIC OF COLOUR AND MOTION}

$A^{T}$ the Physical Society, on November 23, 1878, Prof.

W. E. Ayrton, late of the Imperial Engineering College, Tokio, Japan, read a paper, written by himself and Prof. J. Perry, of the same college, on "The Music of Colour and of Visible Motion." The authors began by pointing out the well-known fact that emotion is excited by moving bodies, and they believed that, upon this basis, a new emotional art would be created which would receive a high development in the far distant future. All methods of exciting emotion could be cultivated; but of these, music, by reason of the facility with which its effects could be produced, had alone been highly perfected by the bulk of mankind. Sculpture and painting are not purely emotional arts, like music, inasmuch as they involve thought. It would take a long time and much culture for the eye to behold moving figures with similar emotional results to those of the ear on hearing sweet sounds; but time and culture only might be necessary. It might be due to their neglect of this emotional tendency that the Western nations felt little emotion at moving visual displays. For among the Eastern nations they had entertainments consisting of motions and dumb show, which, although incomprehensible and even ludicrous to the European, powerfully affected the feelings of a native audience. In Japan the authors had seen whole operas of "melodious motion" performed in the theatres, the emotions being expressed by movements of the body, affecting to the audience, which were quite strange to them. The accompanying orchestral music was, withal, displeasing to the authors, while, on the other hand, Western music is mostly displeasing to the Japanese.

The emotions produced by rapidly-moving masses, such as a train bowling up to a bridge, or by changing colours, as in sunsets, have been felt by all, and those excited when the moving bodies are very large do not 